\title{
Population Structure, Growth, and Age Estimation of Spotted Turtles, Clemmys guttata, Near their Northern Limit: an 18-Year Follow-up
}

\author{
DAVID C. SEBURN \\ Seburn Ecological Services, 920 Mussell Road, RR\#1 Oxford Mills, Ontario K0G 1S0 Canada
}

Seburn, David C. 2003. Population structure, growth, and age estimation of Spotted Turtles, Clemmys guttata, near their northern limit: an 18-year follow-up. Canadian Field-Naturalist 117(3): 436-439.

\begin{abstract}
Mark-recapture and radio telemetry data were collected from 1999-2001 on a population of Spotted Turtles, Clemmys guttata, near their northern limit in Ontario, Canada, and compared with a similar study conducted from 1983-1986. In 1999-2001, 32 Spotted Turtles were caught, 27 of which were adults. Females outnumbered males 3.5:1. The carapace length (CL) of adult males $(108.5 \pm 5.7 \mathrm{~mm})$ and adult females $(106.4 \pm 6.0 \mathrm{~mm})$ did not differ significantly. A minimum of $22 \%$ of juveniles and $40 \%$ of adults marked in 1983-1984 were still alive in 1999-2001. Adult population size was estimated to be 45 (95\% confidence interval: 34-78). The average size of individual adults marked in 1983 (105.6 $\pm 6.0 \mathrm{~mm}$ CL) and recaptured during 1999 $2001(106.3 \pm 5.9 \mathrm{~mm} \mathrm{CL})$ did not differ significantly. There was also no signficant difference in the number of growth lines on adults caught in $1983(12.9 \pm 2.0)$ and $1999(14.0 \pm 2.3)$. Based on the number of growth lines in 1983, these turtles averaged a minimum of 28.9 years in 1999, but actual ages are likely greater. Summer range length averaged $233 \mathrm{~m}$ (range: 200-275 m), while total range length averaged $327 \mathrm{~m}$ (range: 275-375 m).
\end{abstract}

Key Words: Spotted Turtle, Clemmys guttata, demographics, growth, home range, hibernation.

The global status of the Spotted Turtle (Clemmys guttata) is Vulnerable, indicating the species faces "a high risk of extinction in the medium-term future" (Hilton-Taylor 2000). In Canada, the Spotted Turtle is listed as a species of Special Concern (Oldham 1991*). Canadian populations are limited to Ontario, where populations are believed to be declining as a result of habitat loss, degradation and fragmentation, as well as collecting for the pet trade (Seburn and Seburn 2000).

Spotted Turtles are small $(<15 \mathrm{~cm}$ carapace length, CL) and secretive. They frequently make use of a wide variety of habitats in wetland complexes over the course of the year (Ernst et al. 1994); however, populations in eastern Ontario appear to be limited to bogs (Cook et al. 1980). Spotted Turtles can live for over 30 years (Ernst et al. 1994), yet most studies are only a few years long (but see Litzgus and Brooks 1998a). The present study follows up on an intensive mark recapture study which resulted in 39 Spotted Turtles ( 9 juveniles, 12 males and 18 females) being marked in an isolated population at Mer Bleue Bog (Chippindale 1984*, 1985*). A follow-up study was undertaken to determine a current population estimate for management purposes. In addition, recapture data from turtles marked by Chippindale provide an opportunity to determine minimum survivorship and to test whether growth lines accurately reflect age.

\section{Study Area}

Research was carried out at Mer Bleue Bog, a 2500 ha sphagnum bog within the city of Ottawa, Ontario, Canada $\left(45^{\circ} 25^{\prime} \mathrm{N}, 75^{\circ} 25^{\prime} \mathrm{W}\right)$. Mer Bleue Bog is owned by the National Capital Commission and public access is strictly controlled. An internationally significant wet- land, Mer Bleue has been designated a Ramsar site. In the centre of the bog the peat is 3.5-6.5 m thick and it is here that five sandy islands rise through the bog mat (Brunton 1984*). Around and connecting three of the five islands are small ( $<1 \mathrm{~m}$ wide) aquatic channels. There are also a number of ponds $(<3 \mathrm{~m}$ in diameter) created by practice bombing during World War II. The area around the islands is open bog mat with scattered Black Spruce (Picea mariana) and Larch (Larix laricina). The islands also have Trembling Aspen (Populus tremuloides), Largetooth Aspen (P. grandidentata) and Red Maple (Acer rubrum) growing on them. Common plant species in the bog include sphagnum (Sphagnum spp.), Leatherleaf (Chamaedaphne calyculata), Buckbean (Menyanthes trifoliata), Small Cranberry (Vaccinium oxycoccus), and Large Cranberry (V. macrocarpon; Brunton 1984*).

\section{Methods}

Field studies were undertaken from 26 April 1999 until 25 May 2001, with the majority of field work concentrated in the spring and summer of 1999 and the spring of 2001. Turtles were caught by hand. Upon first capture, each turtle was weighed with a Pesola scale $( \pm 2 \mathrm{~g})$ and carapace length (CL) and width and plastron length (PL) and width were measured with vernier calipers $( \pm 0.5 \mathrm{~mm})$. The number of growth lines were counted (when possible) on the left humeral or pectoral scute of the plastron. Unmarked turtles were notched using the system used by Chippindale (Cagle 1939). The sex of adults was determined by examining secondary sex characteristics: males have a pronounced concave plastron and the vent is posterior to the carapace's edge. Raw data are on file with the 
Natural Heritage Information Centre of the Ontario Ministry of Natural Resources in Peterborough.

Telemetry equipment obtained from Holohil Systems (Carp, Ontario) consisted of modified SI-2 transmitters. The transmitters were approximately $10 \times$ $30 \mathrm{~mm}$ and weighed $10 \mathrm{~g}$. Only turtles weighing approximately $200 \mathrm{~g}$ or more had transmitters attached to them. Transmitters were attached to the posterior marginal scute above the hind leg of the turtle using brass screws. Turtles were tracked using a TRX2000S receiver and a three-element folding Yagi antenna.

Spotted Turtle movements were confined to channels within the bog, hence area was not meaningful and home range lengths were calculated. Summer range lengths were defined as the maximum straight line distance crossing the mapped observation points during May to July. Total range lengths included the hibernaculum in the calculation. Adult population size and the $95 \%$ binomial confidence interval were calculated using the program CAPTURE (Rexstad and Burnham 1992*). Size at maturity was based on the smallest turtle I caught that was first marked in 1983. This female was $97.2 \mathrm{~mm} \mathrm{CL}$ and a minimum of 28 years old in 1999, based on the presence of 12 growth lines in 1983 . The smallest male with obvious secondary sexual characteristics was $100.5 \mathrm{~mm}$ CL. Statistical analyses were conducted using MINITAB (Ryan and Joiner 1994). Although Chippindale marked 49 Spotted Turtles (Chippindale 1989) data are only available on the 39 turtles marked in 1983 and 1984 (Chippindale 1984*, 1985*). Research was conducted under the approval of the Wildlife Animal Care Committee of the Ontario Ministry of Natural Resources, protocols \#99-52, 00-52, 01-52.

\section{Results}

I caught 32 Spotted Turtles, 27 of which were adults (Figure 1). The sex ratio of adults was strongly female biased (21 females to 6 males; $3.5: 1 ; \chi^{2}=8.3$, $\mathrm{p}<0.005)$. The average CL of adult males $(108.5 \pm$ $5.7 \mathrm{~mm}, \mathrm{n}=6)$ and adult females $(106.4 \pm 6.0 \mathrm{~mm}$, $\mathrm{n}=21)$ did not differ significantly $(\mathrm{t}=0.79, \mathrm{p}=0.45)$. Similarly, the average weight of males $(187 \pm 21 \mathrm{~g}$, $\mathrm{n}=6)$ and females $(192 \pm 30 \mathrm{~g}, \mathrm{n}=21)$ did not differ significantly $(\mathrm{t}=0.49, \mathrm{p}=0.64)$. The average $\mathrm{CL}$ of adults from Mer Bleue $(106.9 \pm 5.9 \mathrm{~mm}, \mathrm{n}=27)$ and elsewhere in Ontario $(121.4 \pm 7.4 \mathrm{~mm} \mathrm{n}=26$; Haxton 1998) differed significantly $(\mathrm{t}=7.92, \mathrm{p}<0.0001)$.

The adult population size was estimated to be 45 (95\% confidence interval: $34-78$ ) using the 1999-2001 and 58 (95\% confidence interval: 41-108) using Chippindale's 1983-1984 data.

Fourteen of the adults (52\%) I captured were marked by Paul Chippindale in 1983. While 67\% of the males caught had been previously marked, only $48 \%$ of the females were marked. I did not recapture any of the six turtles Chippindale marked in 1984. Twelve of the adults I caught were marked as adults in 1983, hence

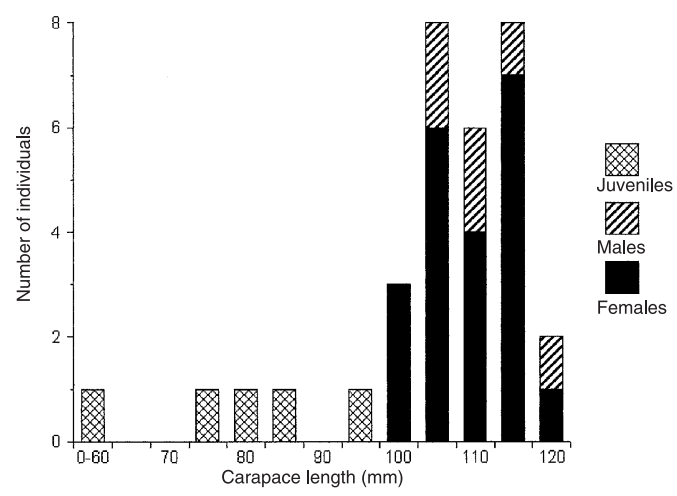

FIGURE 1. Frequency distribution of Spotted Turtles captured at Mer Bleue Bog, Ontario in 1999 and 2001.

a minimum of $40 \%$ of the adults marked in 19831984 were still part of the population 16 years later. In contrast, I captured only $22 \%$ of the juveniles marked by Chippindale in 1983-1984. Although the five smallest turtles Chippindale marked were not recaptured there was no statistically significant difference in the size of the turtles recaptured versus those not recaptured $(\mathrm{W}=310.0, \mathrm{p}=0.52)$.

The average size of nine adults marked in 1983 $(105.6 \pm 6.0 \mathrm{~mm} \mathrm{CL})$ and recaptured during 1999$2001(106.3+5.9 \mathrm{~mm} \mathrm{CL})$ did not differ significantly over time ( $t=0.28, p=0.79$; Figure 2 ). Two juveniles captured during both time periods grew an average of $7.3 \mathrm{~mm}$ (Figure 2). The number of growth lines on seven adults caught in $1983(12.9 \pm 2.0)$ and in 1999 $(14.0 \pm 2.3)$ did not differ significantly over time $(t=0.93, p=0.37)$. Based on the number of growth lines in 1983 and the elapsed time until they were recaptured, these turtles average a minimum of 28.9 years and one turtle was at least 33 years old. There is no reason to assume the number of growth lines in 1983 accurately reflected ages and hence it is likely that these turtles are even older.

Growth data were also collected on one yearling caught on two different occasions. On 20 May 1999, the turtle was $28.4 \mathrm{~mm} \mathrm{CL}$ and $23.0 \mathrm{~mm}$ PL. It was recaptured 41 days later, at which time it was $33.3 \mathrm{~mm}$ $\mathrm{CL}$ and $26.8 \mathrm{~mm} \mathrm{PL}$, an increase of $0.12 \mathrm{~mm} /$ day CL and $0.09 \mathrm{~mm} /$ day PL.

I tracked one male and two females periodically during the summer and fall of 1999 using radio telemetry. The number of observations for each turtle varied from 9 to 10. Turtles appeared to remain within small aquatic channels surrounding and connecting the islands in the bog mat. Summer range length averaged $233 \mathrm{~m}$ (range: 200-275 m) and total range length averaged $327 \mathrm{~m}$ (range: $275-375 \mathrm{~m}$ ). All three turtles hibernated outside of their summer range.

On 15 November 1999, after the turtles had entered hibernation, all three turtles bearing radio transmitters 


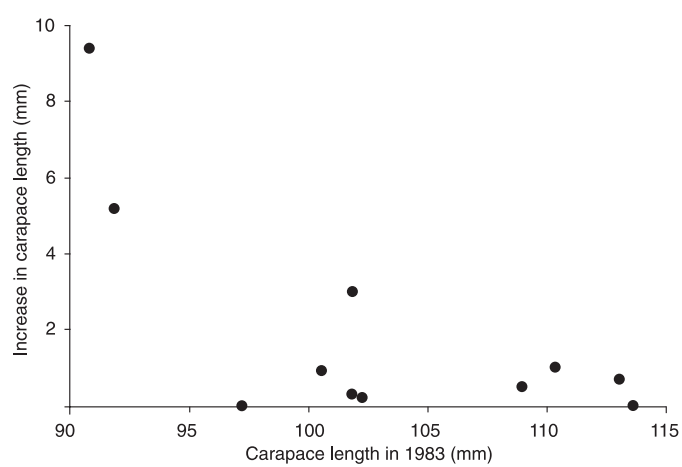

FiguRE 2. Growth of Spotted Turtles marked originally in 1983 and recaptured in 1999 or 2001 at Mer Bleue Bog, Ontario.

were tracked to the same shrubby hummock. It is highly unlikely that only Spotted Turtles with transmitters chose to overwinter in this hummock and this site likely represents a major communal hibernaculum for this population. On 10 April 2001, with some snow still on the ground, six turtles were caught in the vicinity of the known hibernaculum: one turtle was within $10 \mathrm{~m}$ of it, while the other five were approximately $30 \mathrm{~m}$ from it around another hummock. One of these turtles had overwintered at the known hibernaculum in 1999.

\section{Discussion}

Monitoring turtle populations for conservation purposes is challenging. Abundance estimates for adults alone are inadequate to determine the viability of populations given the longevity of adults, hence reproductive rates and age structures should also be monitored (Gibbs and Amato 2000). In the current study, the adult population at Mer Bleue may have declined by $20 \%$ (from 58 to 45) from 1983 to 2001, although this decline is not statistically significant. At the same time the sex ratio became increasingly female biased. Based on the population estimates and sex ratios for the two time periods, there were approximately 35 females and 23 males in 1983-1984, and 35 females and only 10 males in 1999-2001. This suggests a decline in the number of adult males; however, it is also possible that these missing males are merely undetected due to differential catchability. The confirmed presence of juveniles recruited into the adult population and the ongoing presence of juveniles is suggestive of a healthy population. Nonetheless, uncertainty remains: assuming that the 1983-1984 adult population estimate is approximately correct, then I captured roughly $47 \%$ of the adults in 1999-2001. Despite having data on roughly half of the adult population it is not possible to determine if the population has declined by $20 \%$.
The age of turtles has often been estimated by the use of growth lines on the plastron, yet few studies have tested the validity of this method. Adults marked at Mer Bleue in 1983 showed essentially no growth or increase in the number of growth lines over 16-18 years. Similarly, Litzgus and Brooks (1998a, 1998b) found adult Spotted Turtles did not grow appreciably and that the number of growth lines added was consistently less than the number of years that had elapsed. Even in subadult turtles, growth lines are not always produced annually (Brooks et al. 1997). Hence, growth lines appear to be of little value in estimating age after maturity has been reached.

An average total home range length of $327 \mathrm{~m}$ is similar to mean home range lengths of 302 and $320 \mathrm{~m}$ for two populations of Spotted Turtles in Massachusetts (Milam and Melvin 2001). Maximum total range length in the current study was only $375 \mathrm{~m}$, whereas it was over $1000 \mathrm{~m}$ elsewhere in Ontario (Haxton 1998) and in Massachusetts (Milam and Melvin 2001). The difference in movements is likely explained by differences in habitat. Turtles at the other sites were moving among wetlands, whereas the Mer Bleue turtles are confined to the centre of one large bog.

Spotted Turtles at Mer Bleue demonstrate fidelity to a hibernation area, however, not necessarily to the same hibernaculum. Similarly, nine Spotted Turtle hibernacula with up to 34 individuals were found in an $85 \mathrm{~m}^{2}$ area of a fen in Ohio (Lewis and Ritzenthaler 1997). Results from the previous study at Mer Bleue suggest the known hibernation area has been used since at least the winter of 1983-1984 (Chippindale $\left.1985^{*}\right)$. Such fidelity to a hibernation area emphasizes the importance of certain habitats. At Mer Bleue, a circle with radius $400 \mathrm{~m}$ centred on the known hibernation area would enclose the activity areas of the three turtles with transmitters. Given the fact that there was very little movement of turtles among some of the islands and that turtles have been captured at other areas of the bog early in the season, it is most probable that there is more than one hibernation centre. Other studies of Spotted Turtles also support the notion of multiple hibernation centres. Individuals in one population hibernated in at least three different small bogs (Haxton and Berrill 1999), while in another population 18 hibernacula were found in five different sphagnum swamps (Litzgus et al. 1999). Effective management of Spotted Turtle populations should focus on identifying and ensuring the protection of all major hibernacula and the habitat that connects them.

\section{Acknowledgments}

I am grateful to the Ottawa Stewardship Council for coordinating this project and to the National Capital Commission for allowing me to work at Mer Bleue. Financial support in 1999 came from the Mountain Equipment Co-op, the Community Fisheries and Wild- 
life Involvement Program (CFWIP) of the Ontario Ministry of Natural Resources, and the Community Environmental Grants Program (CEPGP) of the then Regional Municipality of Ottawa-Carleton. Support in 2001 was provided by the Species at Risk fund of the Ontario Ministry of Natural Resources. Special thanks to Leslie Bol for assisting with the field work in 1999. I am indebted to Paul Chippindale, whose dedicated work in the 1980s helped put my own humble efforts into a broader and more meaningful context. My deepest thanks go to Carolyn Seburn, who helped with many aspects of the project, but missed out on the fun of wading hip-deep in bog water. Francis Cook, Tim Haxton, Carolyn Seburn and two anonymous reviewers provided helpful comments on earlier drafts of this manuscript.

Documents Cited (marked * in text)

Brunton, D. F. 1984. The vegetation and flora of the Mer Bleue Conservation Area, National Capital Commission Greenbelt, Ottawa-Carleton, Ontario. Conservation Studies 22, National Capital Commission, Ottawa.

Chippindale, P. 1984. A Study of the Spotted Turtle (Clemmys guttata) in Mer Bleue Bog. Conservation Studies Publication Number 25, National Capital Commission, Ottawa, Ontario. 84 pages.

Chippindale, P. 1985. The Mer Bleue Spotted Turtles: results of 1984 study. Conservation Studies Publication Number 37, National Capital Commission, Ottawa, Ontario. 7 pages.

Oldham, M. J. 1991. Status report on the Spotted Turtle, Clemmys guttata, in Canada. Committee on the Status of Endangered Wildlife in Canada (COSEWIC), Ottawa, Ontario.

Rexstad, E., and K. Burnham. 1992. User's Guide for Interactive Program CAPTURE - Abundance estimation of closed animal populations. Self-published document.

\section{Literature Cited}

Brooks, R. J., M. A. Krawchuk, C. Stevens, and N. Koper. 1997. Testing the precision and accuracy of age estimation using lines in scutes of Chelydra serpentina and Chrysemys picta. Journal of Herpetology 31: 521-529.

Cagle, F. R. 1939. A system of marking turtles for future identification. Copeia 1939: 170-173.

Chippindale, P. 1989. Courtship and nesting records for Spotted Turtles, Clemmys guttata in Mer Bleue Bog, southeastern Ontario. Canadian Field-Naturalist 103: 289-291.
Cook, F. R., J. D. LaFontaine, S. Black, L. Luciuk, and R. V. Lindsay. 1980. Spotted Turtles (Clemmys guttata) in eastern Ontario and adjacent Quebec. The Canadian FieldNaturalist 94: 441-415.

Ernst, C. H., J. E. Lovich, and R. W. Barbour. 1994. Turtles of the United States and Canada. Smithsonian Institution, Washington D.C.

Gibbs, J. P., and G. D. Amato. 2000. Genetics and demography in turtle conservation. Pages 207-217 in Turtle Conservation. Edited by M. W. Klemens. Smithsonian Institution Press, Washington, D.C.

Haxton, T. J. 1998. Home range and habitat selectivity of Spotted Turtles (Clemmys guttata) in central Ontario: Implications for a management strategy. Master's thesis, Trent University, Peterborough, Ontario

Haxton, T., and M. Berrill. 1999. Habitat selectivity of Clemmys guttata in central Ontario. Canadian Journal of Zoology 77: 593-599.

Hilton-Taylor, C. 2000. 2000 IUCN Red List of Threatened Species. International Union for Conservation of Nature and Natural Resources, Gland, Switzerland and Cambridge, UK.

Lewis, T. L., and J. Ritzenhaler. 1997. Characteristics of hibernacula use by spotted turtles, Clemmys guttata, in Ohio. Chelonian Conservation and Biology 2: 611-615.

Litzgus, J. D., and R. J. Brooks. 1998a. Growth in a cold environment: body size and sexual maturity in a northern population of spotted turtles, Clemmys guttata. Canadian Journal of Zoology 76: 773-782.

Litzgus, J. D., and R. J. Brooks. 1998b. Testing the validity of counts of plastral scute rings in spotted turtles, Clemmys guttata. Copeia 1998: 222-225.

Litzgus, J. D., J. P. Costanzo, R. J. Brooks, and R. E. Lee, Jr. 1999. Phenology and ecology of hibernation in spotted turtles (Clemmys guttata) near the northern limit of their range. Canadian Journal of Zoology 77: 1348-1357.

Milam, J. C., and S. M. Melvin. 2001. Density, habitat use, movements, and conservation of spotted turtles (Clemmys guttata) in Massachusetts. Journal of Herpetology 35: 418-427.

Ryan, B. F., and B. L. Joiner. 1994. Minitab Handbook. Third edition. Duxbury Press, Belmont California.

Seburn, D., and C. Seburn. 2000. Conservation Priorities for the Amphibians and Reptiles of Canada. World Wildlife Fund Canada and Canadian Amphibian and Reptile Conservation Network.

Received 10 February 2002

Accepted 10 February 2004 